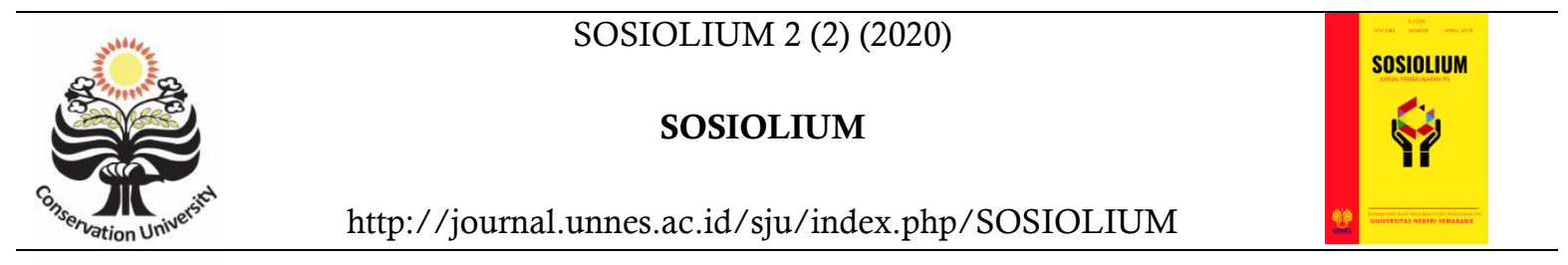

\title{
PEWARISAN NILAI-NILAI SEDEKAH BUMI PADA GENERASI MUDA DI DUSUN TABAN DESA JENENGAN KECAMATAN KLAMBU KABUPATEN GROBOGAN
}

\section{Lainnatu Julniyah, Asep Ginanjar}

Prodi Pendidikan IPS, Fakultas Ilmu Sosial, Universitas Negeri Semarang, Indonesia.

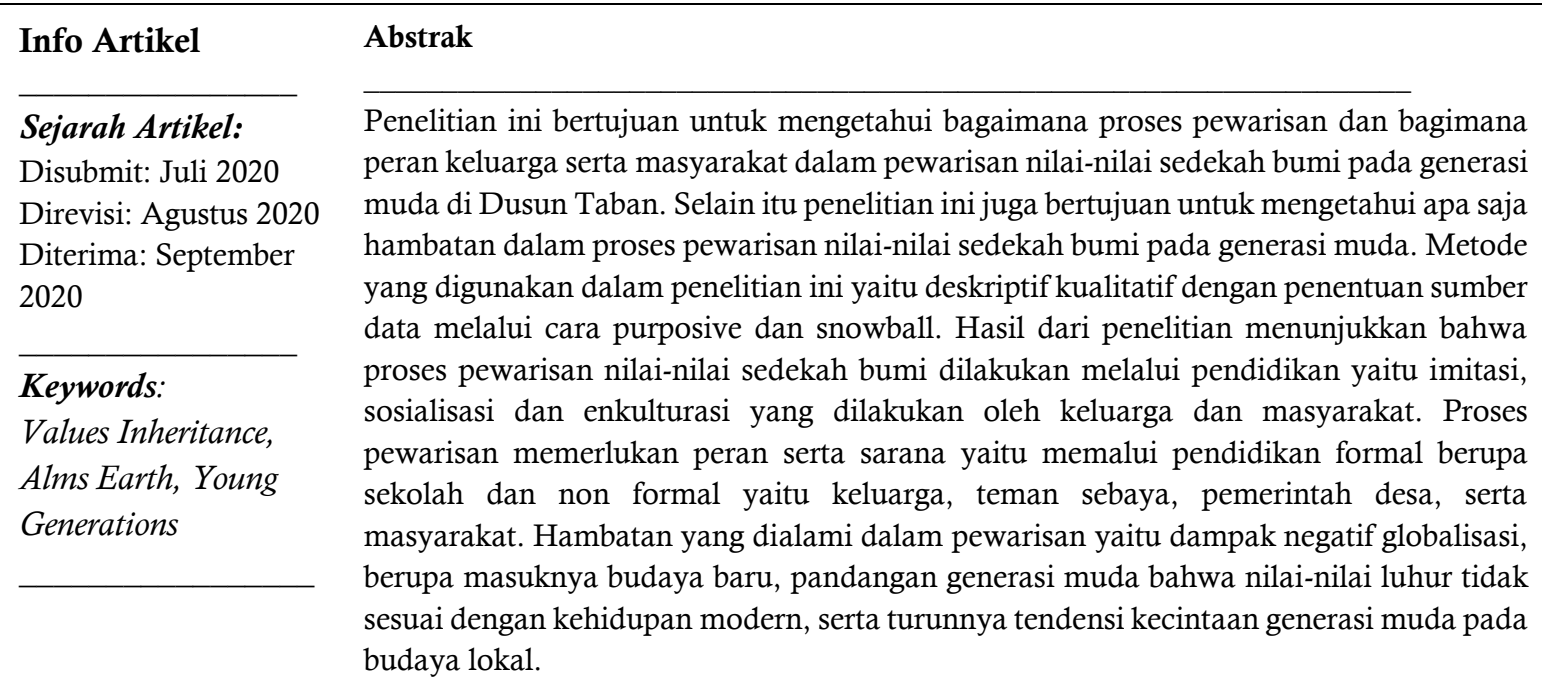

Abstract

This study is aimed to find out how the inheritance process and the role of families and society in inheriting the alms earth values to the young generations in Taban. In addition, this study is aimed to find out the obstacles in the process of inheriting the alms earth values to the young generations. The method used in this study is descriptive qualitative with data selection sources through purposive and snowball. The results of this study showed that the process of inheriting alms earth values was carried out through education done by families and society namely imitation, socialization and enculturation. The inheritance process requires the contribution of facilities through formal education like schools and non-formal education like family, peers, local government, and society. The obstacles in inheriting process are the negative impacts of globalization, like the presence of new cultures, the viewpoint of young generations that the noble values are not suitable with modern life, and the degradation tendency of the young generations' affiliation to local culture.

(C) 2020 UniversitasNegeri Semarang

\footnotetext{
Alamat korespondensi:

E-ISSN 2685-4929

Gedung C1, Lantai 1, FIS Unnes

Kampus Sekaran, Gunungpati, Semarang, 50229

Email: asep.ginanjar@mail.unnes.ac.id
} 


\section{PENDAHULUAN}

Indonesia merupakan negara kepulauan yang memiliki berbagai macam kebudayaan. Misalnya di daerah Jawa, antara masyarakat Jawa yang hidup di daerah pesisir akan memiliki budaya yang berbeda dengan masyarakat Jawa yang hidup di pedalaman. Kebudayaan yang berbeda tersebut harus dilestarikan. Menurut Permendikbud No.10 Tahun 2014 Pasal 1 menyebutkan bahwa maksud dari pelestarian tradisi yaitu upaya perlindungan, pengembangan, dan pemanfaatan suatu kebiasaan dari kelompok masyarakat pendukung kebudayaan yang penyebaran dan pewarisannya berlangsung secara turun-temurun.

Di dalam pewarisan kebudayaan terdapat tiga unsur utama yang harus diwariskan, yaitu pertama unsur-unsur apa saya yang diwariskan yaitu berupa adat istiadat, nilai-nilai budaya, dan pandangan hidup dalam masyarakat, kedua proses transmisi yaitu berupa proses imitasi, identifikasi dan sosialisasi, dan ketiga cara transmisi meliputi peran serta dan bimbingan (Fortes dalam Tilaar, 1999:54).

Pewarisan suatu kebudayaan tidak hanya dilakukan secara vertikal, akan tetapi dapat dilakukan horizontal, yaitu manusia yang satu dapat belajar dengan manusia yang lainnya yang mengetahui kebudayaan tersebut.

Pewarisan kebudayaan tidak dapat lepas dari sistem pendidikan sebab dalam kebudayaan terkandung tiga aspek yaitu: kebudayaan dialihkan dari generasi ke generasi lainnya karena kebudayaan dipandang sebagai suatu warisan atau tradisi sosial, kebudayaan dipelajari, dalam hal ini kebudayaan bukanlah pengejawantahan dalam kadar tertentu dari keadaan jasmani manusia yang bersifat genetik, dan kebudayaan itu dihayati dan dimiliki bersama oleh para warga masyarakat pendukungnya (Persons dalam Rohidi, 1994:6). Berdasarkan dari pernyataan Persons, maka dalam pewarisan suatu kebudayaan dapat dilakukan dengan proses belajar, sebab kebudayaan merupakan warisan dan tradisi sosial yang dimiliki oleh masyarakat pendukungnya.

Proses pewarisan kebudayaan dengan belajar dapat dilakukan dengan cara sosialisasi dan enkulturasi pada generasi muda. Proses belajar kebudayaan dapat dilakukan dengan tiga cara yaitu internalisasi, sosialisasi dan enkulturasi (Koentjaraningrat, 2015:184). Pendapat tersebut didukung oleh Ahmadi (2007:61) yang menyatakan bahwa kebudayaan adalah milik dan warisan sosial, kebudayaan terbentuk dalam dan dengan interaksi sosial dan diwariskan kepada generasi mudanya dengan cara enkulturasi atau pendidikan. Selain enkulturasi, proses belajar pewarisan kebudayaan dilakukan melalui sosialisasi (Tilaar, 1999:54). Sosialisasi atau pemasyarakatan adalah individu menyesuaikan individu lain dalam masyarakat. Proses belajar dalam pewarisan perlu adanya peran serta sarana yang mendukung hal-hal yang diwariskan.

Sarana yang mendukung dalam pewarisan kebudayaan yaitu yang sering dijumpai oleh generasi muda dalam kehidupannya, misalnya keluarga, masyarakat, sekolah, dan teman sebaya. Menurut Herimanto (2011:34) proses enkulturasi dimulai sejak dini, yaitu masa kanakkanak, bermula dari lingkungan keluarga, teman sepermainan dan masyarakat luas. Oleh sebab itu, dalam pewarisan nilai-nilai kebudayaan perlu adanya peran baik keluarga maupun masyarakat. Keluarga merupakan pendidik pertama bagi seorang anak sehingga bentuk kepribadian anak sangat bergantung pada pendidikan di dalam sebuah keluarga. Selain keluarga masyarakat juga memiliki peran dalam pewarisan kebudayaan yaitu dengan berpartisipasi. Partisipasi masyarakat dapat diartikan sebagai keterlibatan seseorang ke dalam interaksi sosial dalam situasi tertentu (Wasir dalam Normina, 2016:72). Partisipasi masyarakat dapat berupa bentuk partisipasi finansial, partisipasi material, partisipasi akademik, partisipasi kultur dan partisipasi evaluatif (Conyers dalam normina, 2016:72)

Salah satu kebudayaan di Indonesia yang perlu diwariskan yaitu tradisi sedekah bumi. Tradisi sedekah bumi merupakan salah satu tradisi yang harus diwariskan pada generasi muda, sebab dalam tradisi sedekah bumi memiliki nilai-nilai luhur yang hidup di dalam masyarakat. Nilai-nilai tersebut harus diwariskan, akan tetapi dalam pewarisan akan 
mengalami hambatan dan tantangan. Tantangan yang dihadapi yaitu dengan adanya kemajuan teknologi dan komunikasi (Tilaar, 1999:55). Kemajuan zaman yaitu era globalisasi menjadikan semakin canggihnya teknologi dan komunikasi. Selain itu juga mempermudah aksesbilitas dalam berbagai bidang di dunia baik bidang ekonomi, teknologi, pendidikan, budaya, maupun politik. Dampak negatif dari globalisasi bagi pewarisan tradisi yaitu mudahnya budaya Barat masuk ke Indonesia.

Tradisi sedekah bumi merupakan salah satu dari beberapa tradisi yang ada di Dusun Taban Desa Jenengan Kecamatan Klambu Kabupaten Grobogan. Tradisi tersebut memiliki nilai-nilai luhur yang perlu diwariskan pada generasi muda di Dusun Taban, sebab nilai-nilai luhur tersebut hidup di dalam mayarakat. Nilai-nilai sedekah bumi dijadikan acuan dalam mendidik para generasi muda. Oleh karena itu, tradisi sedekah bumi di Dusun Taban harus diwariskan, dengan begitu para generasi muda akan menanamkan nilai-nilai tersebut dalam kepribadiannya. Akan tetapi dalam kenyataannya tidak semua generasi muda menanamkan nilai-nilai luhur dalam kehidupan sehari-hari, malah ada yang bertolak belakang dengan nilai-nilai tersebut. Nilai-nilai yang dimaksud yaitu nilai-nilai menurut Hadikusumo dalam Bara (2013:17) yang berupa nilai pendidikan ketuhanan, nilai pendidikan sosial atau kemasyarakatan dan nilai pendidikan moral. Nilai-nilai tersebut harus wariskan pada generasi muda agar generasi muda dapat menyesuaikan dengan nilai-nilai yang ada di dalam masyarakat.

Berdasarkan ulasan diatas peneliti tertarik untuk mengetahui bagaimana proses pewarisan nilai-nilai sedekah bumi pada generasi muda di Dusun Taban. bagaimana peran keluarga dan masyarakat dalam pewarisan nilai-nilai sedekah bumi. Dan apakah dalam pewarisan nilai-nilai sedekah bumi pada generasi muda di Dusun Taban terdapat hambatan.

\section{METODE PENELITIAN}

Metode penelitian yang digunakan oleh peneliti yaitu deskriptif kualitatif. Penggunaan metode deskriptif kualitatif disesuaikan dengan tujuan utama peneliti yaitu untuk mendiskripsikan, mempelajari, menerangkan atau menginterpretasikan suatu fenomena yang diperoleh dan menganalisisnya dalam bentuk kata-kata guna memperoleh kesimpulan tentang pewarisan nilai-nilai sedekah bumi pada generasi muda di Dusun Taban. Penelitian ini menggunakan cara purposive dan snowball dalam pengambilan sumber informan. Teknik pengumpulan data yang digunakan yaitu observasi, wawancara dan dokumentasi. Penelitian ini dalam menganalisis data menggunakan analisis interaktif model yaitu berupa pengumpulan data, reduksi data, penyajian data dan verifikasi.

\section{PEMBAHASAN}

\section{Proses pewarisan nilai-nilai sedekah bumi}

Masyarakat Dusun Taban merupakan masyarakat yang memiliki berbagai kebudayaan. Salah satu kebudayaan yang harus diwariskan pada generasi muda yaitu tradisi sedekah bumi. Tradisi sedekah bumi merupakan salah satu bentuk upacara sakral, sehingga perlu dilestarikan (Permendikbud No.10 tahun 2014). Selain upacara sakral, dalam tradisi sedekah bumi di Dusun Taban juga memiliki nilai-nilai luhur yang dijadikan sebagai pedoman di dalam masyarakat. Oleh sebab itu, tradisi sedekah bumi perlu diwariskan pada generasi muda.

Pewarisan nilai-nilai yang terdapat dalam sedekah bumi tidak hanya dilakukan secara vertikal saja, akan tetapi dapat dilakukan dengan cara horizontal yaitu belajar dengan proses pendidikan sosialisasi dan enkulturasi. Menurut Fortes dalam Tilaar (1999: 54) terdapat tiga proses transmisi budaya. Pertama yaitu adat istiadat dalam proses sedekah bumi, kesenian, dan nilai-nilai yang terdapat dalam sedekah bumi. Nilai-nilai yang terdapat dalam sedekah bumi yang diwariskan pada generasi muda yaitu.

1. Nilai gotong royong, yaitu terjadi ketika persiapan pelaksanaan kirab budaya. Masyarakat sangat berpartisipasi dan bekerjasama dalam membuat kreasi dari hasil bumi yang disebut dengan "ogohogoh".

2. Nilai ketuhanan, masyarakat bersyukur atas limpahan rizky yang diberikan oleh Allah SWT dengan melalui hasil bumi yang melimpah. Bentuk rasa syukur yang 
dilakukan oleh masyarakat Taban yaitu dengan melakukan tahlilan di musala masing-masing RT.

3. Nilai sosial atau masyarakat, yaitu bentuk interaksi yang terjadi antar masyarakat baik dalam persiapan maupun pelaksanaan sedekah bumi.

4. Nilai persatuan dan kesatuan, masyarakat beranggapan bahwa manusia tidak dapat hidup sendiri dan memerlukan bantuan orang lain. Sehingga dalam tradisi sedekah bumi warga bersatu, bekerjasama dan berpartisipasi untu menyelesaikan kepentingan bersama.

5. Nilai kesenian, kesenian dalam tradisi sedekah bumi di Dusun Taban terlihat pada semua acara, mulai dari kirab budaya, pementasan wayang sampai dengan tayuban.

6. Nilai bahasa, adanya tradisi sedekah bumi dapat mengajarkan para generasi muda mengenai bahasa daerah yaitu Bahasa Jawa yang ada pada saat pementasan wayang, sehingga generasi muda dapat belajar bahasa daerah.

7. Nasionalisme, dengan membudayakan dan membiasakan tradisi sedekah bumi pada generasi muda, maka pada jiwa generasi muda akan tumbuh jiwa nasionalisme pada budaya lokal.

8. Nilai pendidikan moral, adanya tradisi sedekah bumi yaitu pementasan wayang akan mendidik anak-anak tentang kebaikan dan keburukan, sebab dalam pementasan wayang yang menceritakan cerita-cerita Jawa mengandung nilai kebaikan dan keburukan. Sehingga generasi muda mengerti apa yang harus dilakukan dan yang harus dihindari serta ditinggalkan.

Proses pewarisan yang kedua yaitu melalui imitasi, identifikasi dan sosialisasi. Proses belajar kebudayaan ada tiga yaitu internalisasi, sosialisasi dan enkulturasi (Koentjaraningrat, 2015:184). Proses transmisi di Dusun taban dilakukan dengan cara imitasi, sosialisasi dan enkulturasi. Proses imitasi dilakukan anak dengan meniru apa yang dilakukan oleh orang tua mereka. Orang tua memberikan contoh dengan berpartisipasi dalam penyelenggaraan tradisi sedekah bumi serta mengajak anaknya untuk ikut. Dengan memberi contoh dan ajakan maka anak akan mulai terbiasa mengikuti tradisi tersebut. Sosialisasi pertama kali dilakukan oleh orang tua. Orang tua melakukan sosialisasi kepada anak berupa adat istiadat, kesenian serta nilai-nilai luhur yang ada di dalam masyarakat. Sosialisasi yang dilakukan oleh orang tua kepada anak mengenai nilai-nilai luhur dimaksudkan agar anak dapat hidup sesuai dengan nilai-nilai ada di dalam masyarakat. Selain sosialisasi, pembudayaan juga dilakukan oleh orang tua pada anak sejak usia dini. Sejak dini anak akan diperkenalkan kebudayaan yang ada di dalam masyarakat, tujuannya yaitu agar anak mewarisi kebudayaan sedekah bumi. Apabila tradisi sedekah bumi sudah ternanan pada diri anak, maka nilai-nilai yang terdapat dalam tradisi sedekah bumi akan melekat pada diri seorang anak. Oleh karena itu, melalui imitasi, sosialisasi dan enkulturasi tradisi sedekah bumi dapat diwariskan pada generasi muda serta nilai-nilai yang ada di dalam sedekah bumi seperti nasionalisme, ketuhanan, gotong royong, sosial serta moral akan tertanan dalam jiwa anak.

Unsur yang ketiga yaitu cara transmisi berupa peran serta dan bimbingan. Proses pewarisan nilai-nilai sedekah bumi memerlukan peran dan sarana supaya tujuan dari pewarisan nilai-nilai sedekah bumi tercapai. Sarana pewarisan yaitu berupa keluarga, teman sepermainan, dan masyarakat luas (Herimanto, 2011:34). Sarana dalam pewarisan tradisi tidak hanya dilakukan melalui pendidikan non formal yaitu keluarga, teman sepermainan, pemerintah, dan masyarakat. sarana pewarisan juga dapat dilakukan melalui pendidikan formal yaitu dengan cara mengintegrasikan pada mata pelajaran atau mata kuliah yang bersifat pembinaan budi pekerti, ilmu budaya dasar, dan humaniora yang mencakup nilai-nilai religius, nilai seni, etika, moral logika, keadilan, kejujuran dan nilai kemanusiaan lainnya (Sumardjo dalam Tuloni, 2003:18). Pada pewarisan nilai-nilai sedekah bumi di Dusun Taban dilakukan melalui peran dari orang tua, teman sebaya, sekolah, masyarakat, dan pemerintah desa. 


\section{Peran keluarga dan masyarakat}

Keluarga sangat berperan penting dalam pembentukan kepribadian seorang anak, sebab keluarga adalah pendidik pertama bagi seorang anak. kepribadian anak tidak akan lepas dari kepribadian orang tuanya. Menurut Dorothy dalam Bahri (2004:25) baik tidaknya seorang anak bergantung dari cara orang tua dalam mendidik seorang anak. Jika anak dibesarkan dengan celaan, maka ia belajar memaki. Jika anak dibesarkan dengan toleransi, maka ia akan belajar menahan diri. Jika anak dibesarkan dengan sebaik-baiknya perlakuan, maka ia belajar keadilan. Dalam proses pewarisan nilainilai sedekah bumi di Dusun Taban orang tua berperan untuk mengajak dan menjadi panutan bagi seorang anak. Selain itu, orang tua juga harus mengenalkan nilai-nilai yang terdapat di dalam masyarakat yang harus dijadikan pedoman bagi seorang anak.

Para orang tua di Dusun Taban selalu mengajak anaknya untuk berpartisipasi dalam pelaksanaan tradisi sedekah bumi. Mereka sadar bahwa generasi muda adalah generasi penerus sehingga para generasi muda harus diperkenalkan dengan tradisi yang ada di dalam masyarakat. Peran orang tua dalam mewariskan nilai-nilai sedekah bumi pada generasi muda selain dengan memberikan contoh dan menyosialisasi nilai-nilai yang ada dalam masyarakat, mereka juga membiasakan anaknya untuk berpartisipasi dalam tradisi sedekah bumi mulai dari persiapan sampai pelaksanaan tradisi. Mereka beranggapan bahwa dengan membiasakan anak dengan mengikuti tradisi sedekah bumi, maka anak akan terbiasa dan membudayakan tradisi tersebut pada kehidupannya. Apabila generasi muda sudah mencintai tradisi sedekah bumi, maka nilai-nilai yang ada dalam tradisi sedekah bumi akan tertanam pada jiwa generasi muda.

Selain orang tua, masyarakat juga memiliki peran dalam pewarisan nilai nilai sedekah bumi. Partisipasi yang dilakukan masyarakat secara sadar ke dalam suatu interksi dalam situasi tertentu (Wasir dalam Normina, 2016:72) merupakan bentuk peran masyarakat. Partisipasi mayarakat Dusun Taban dalam pewarisan nilainilai sedekah bumi yaitu dengan mendukung penuh terselenggaranya tradisi tersebut. Bentuk partisipasi yang dilakukan oleh masyarakat Dusun Taban yaitu secara material dan kultur. Mereka ikut serta dalam memberikan dana untuk menyelenggarakan tradisi sedekah bumi. Selain itu, mendukung penuh dari masyarakat yaitu dengan mengajak generasi muda untuk berpartisipasi baik dalam persiapan maupun pelaksanaan. Masyarakat mengajak anak-anak apabila ada orang tua dari anak tersebut yang tidak dapat ikut berpartisipasi.

Teman sebaya sangat mempengaruhi pewarisan tradisi sedekah bumi, sebab adanya teman sebaya mempengaruhi minat tidaknya para generasi muda untuk berpartisipasi. Akan tetapi di Dusun Taban para generasi muda selalu ikut berpartisipasi, karena teman sepergaulan yang ada di dusun tersebut selalu mengajak apabila ada tradisi sedekah bumi. Sehingga dengan ajakan teman sepermainan tersebut akan membantu proses pewarisan. Hal tersebut dikarenakan mampu mengajak generasi muda untuk mengikuti dan menonton serangkaian acara sedekah bumi mulai dari doa atau tahlilan, kirab budaya, wayang dan tayuban.

Sarana pewarisan selanjutnya yaitu pemerintah desa. Di Dusun Taban pemerintah desa sangat mendukung terselenggaranya tradisi sedekah bumi. Dukungan yang diberikan yaitu berupa pendaan penyelenggaraan tradisi serta partisipasi perangkat desa yang menyaksikan serangkaian acara sedekah bumi. Bentuk dukungan tersebut merupakan bentuk pewarisan yang dilakukan oleh pemerintah desa, sebab dengan dukungan tersebut tradisi sedekah bumi dapat berlangsung dengan lancar.

Selain sarana pewarisan tradisi melalui pendidikan non formal diatas, pewarisan tradisi juga dilakukan melalui pendidikan formal yaitu sekolah. pewarisan yang dilakukan di dalam sekolah yaitu dengan mengintegrasikan nilainilai kebudayaan dalam mata pelajaran. Meskipun di dalam sekolah pengaplikasiannya sempit, akan tetapi dengan mengintegrasikan nilai-nilai tersebut pada mata pelajaran diharapkan peserta didik mampu mengaplikasikannya di dalam kehidupan bermasyarakat. 


\section{Hambatan-hambatan dalam pewarisan}

Proses pewarisan kebudayaan dari satu generasi ke generasi selanjutnya tidak serta merta berjalan dengan lancar. Proses pewarisan kebudayaan mengalami hambatan-hambatan, hambatan yang dirasakan yaitu dampak negatif dari globalisasi khususnya di bidang budaya. Semakin majunya zaman, maka teknologi informasi dan komunikasi akan semakin maju, sehingga proses transmisi kebudayaan akan mengalami hambatan yang berat (Tilaar, 1999:55). Globalisasi mempermudah aksisbilitas antar negara termasuk dalam bidang budaya. Mudahnya budaya baru masuk ke Indonesia menjadi hambatan bagi masyarakat dalam melakukan proses pewarisan budaya lokal, sebab generasi muda lebih tertarik dengan budaya baru.

Hambatan-hambatan yang dirasakan oleh masyarakat Dusun Taban dalam melakukan pewarisan nilai-nilai sedekah bumi yaitu adanya dampak negatif dari globalisasi. Salah satu efek dari globalisasi di bidang budaya yaitu generasi muda menolak kebudayaan lokal dan menerima budaya baru yang datang dalam kehidupan mereka. Penolakan tersebut dikarenakan budaya lokal dianggap tidak sesuai dengan perkembangan zaman dan bertolak belakang dengan kehidupan sekarang ini (Herimanto, 2011:34). Budaya baru yang diterima oleh generasi muda di Dusun Taban berawal dari lingkungan luar yaitu pergaulan dan lingkungan kerja. Generasi muda yang bekerja merantau akan menemukan budaya baru dan budaya tersebut dibawa pulang serta dilakukan dalam kehidupan sehari-hari di dalam masyarakat.

Selain itu, hambatan lain yang dirasakan yaitu anggapan generasi muda pada nilai-nilai luhur yang sudah tidak sesuai dengan kehidupan yang lebih modern. Turunnya tendensi kecintaan generasi muda pada budaya lokal juga menghambat pewarisan tradisi (Suneki, 2012:309). Hal tersebut terlihat dari cara berpakaian dan cara bicara para genrasi muda yang meniru budaya barat. Menurut masyarakat Taban hal tersebut sangat menghamat dalam proses pewarisan nilai-nilai tradisi sedekah bumi.

\section{SIMPULAN}

Berdasarkan dari pembahasan di atas maka simpulan dalam artikel ini adalah:

1. Pewarisan tradisi sedekah bumi di Dusun Taban yaitu berupa adat istiada dalam tradisi sedekah bumi, kesenian berupa kirab budaya, wayang dan Tari Tayub serta nilainilai luhur. Nilai-nilai dalam tradisi sedekah bumi yang diwariskan yaitu nilai ketuhanan, gotong royong, sosial atau kemasyarakatan, nilai persatuan dan kesatuan atau guyub, nasionalisme, bahasa, kesenian dan nilai moral. Proses pewarisan yang dilakukan yaitu melalui proses imitasi, sosialisasi dan enkulturasi atau pembudayaan yang dilakukan melalui orang tua dan masyarakat. Pada proses pewarisan terdapat cara pewarisan yaitu dengan peran serta. Peran serta dalam proses pewarisan nilai-nilai sedekah bumi yaitu melalui sarana pendidikan baik formal yaitu sekolahan dan non formal yaitu keluarga, masyarakat, pemerintah, serta teman sebaya.

2. Peran keluarga khususnya orang tua dalam pewarisan nilai-nilai sedekah bumi yaitu dengan memberikan contoh, mengajak serta menjadi panutan bagi anak agar ikut berpartisipasi dalam tradisi sedekah bumi. Selain keluarga masyarakat dan pemerintah desa juga ikut berperan dalam pewarisan nilai-nilai sedekah bumi yaitu dengan memberikan dukungan berupa dana dalam penyelenggaraan sedekah bumi. Sarana lain yang berperan yaitu teman sebaya dan sekolah. teman sebaya berpengaruh pada ikut tidaknya generasi dalam tradisi sedekah bumi, sedangkan sekolah berperan dalam mengintegrasikan nilai-nilai tradisi dalam mata pelajaran.

3. Hambatan yang dialami oleh warga yaitu dampak negatif dari globalisasi berupa masuknya budaya barat, anggapan bahwa nilai-nilai kebudayaan sudah tidak sesuai dengan kehidupan yang modern, serta turunnya tendensi kecintaan generasi muda pad budaya lokal. 


\section{SARAN}

Proses pewarisan nilai-nilai tradisi sedekah bumi sebaiknya tidak hanya dilakukan terfokus oleh lingkungan keluarga. Pewarisan tersebut dapat dilakukan dengan dukungan pemerintah desa serta masyarakat yaitu dengan adanya sanggar kesenian. Sanggar kesenian dapat membantu pewarisan nilai-nilai budaya lokal, sebab dalam tradisi sedekah bumi terdapat nilai kesenian dan nasionalisme, maka dengan adanya sanggar kesenian para generasi muda dapat belajar tentang kesenian, seperti tarian, wayang maupun gamelan. Dengan begitu nilainilai tersebut akan tertanam pada jiwa generasi muda.

\section{DAFTAR PUSTAKA}

Ahmadi, Abu. 2007. Sosiologi Pendidikan. Jakarta: Rineka Putra.

Bara Wati, Herlian. 2013. 'Pengaruh dan Nilainilai Pendidikan Upacara Sedekah Bumi terhadap Masyarakat Desa Bagung Sumberhadi Kecamatan Prembun Kabupaten Kebumen'. Skripsi. Purwokerto: Universitas Muhammadiyah Purwokerto.

Hermanto. 2011. Ilmu Sosial dan Budaya Dasar. (ceteakan ke-4) Jakarta: Bumi Aksara.
Hidayat, Ade. 2017. 'Pola Pewarisan Nilai yang Berimplikasi Bimbingan pada Pancakaki Bani Nuryayi'. Dalam JOMSIGN:Journal of Multikultural Studies in Guidance and Counseling. No. 1. Hlm. 99-122.

Koentjaraningrat. 2015. Pengantar Ilmu Antropologi. Jakarta: Rineka Putra.

Normina. 2016. 'Partisispasi Masyarakat dalam Pendidikan'. Ittihad Jurnal Kopertais Wilayah XI Kalimantan. No. 16. Hlm. 71-85.

Permendikbud Nomor 10 Tahun 2014 Tentang Pedoman Pelestarian Tradisi.

Rohidi, Tjetjep Rohendi. Dkk. 1994. Pendekatan Sistem Sosial Budaya dalam Pendidikan. Semarang: IKIP Semarang Press.

Suneki, Sri. 2012. 'Dampak Globalisasi Terhadap Eksistensi Budaya Daerah'. Dalam Ilmiah Civis. No. 1. Hal. 307-321.

Tilaar. 1999. Pendidikan, Kebudayaan, dan Masyarakat Madani Indonesia. Bandung: PT. Remaja Rosdakarya.

Tuloni, Nani dkk. 2003. Dialog Budaya Wahana Pelestarian dan Pengembangan Kebudayaan Bangsa. Jakarta: CV Mitra Sari. 